\author{
International Journal of Global Accounting, Management, Education, \\ and Entrepreneurship (IJGAME 2) \\ URL : https://jurnal.stiepemuda.ac.id/index.php/ijgame2 \\ P- ISSN : :2723-2948 \\ E-ISSN : 2723-2204
}

\title{
THE EFFECT OF EXCESSIVE SETTING TIME, LONG DAMAGE OF THE MACHINE, TIME OF PACKAGING PACKAGES STOPPED TO PRODUCTION OPERATIONAL COSTS: STUDY IN LINE 8A PT XYZ FARMA Tbk
}

\author{
A Ashwatu Nida Dipajana ${ }^{1}$; Iha Haryani $\mathrm{H}^{2}$ \\ dipayanaahmad@gmail.com ${ }^{1}$; ) iha.haryani@yahoo.com ${ }^{2}$ \\ Pancasila University
}

\begin{abstract}
This study aims to determine the effect of excess machine setting time, machine breakdown time, time for packaging lines to stop, on production operating costs and which factors are most dominant in influencing production operating costs. This research uses a quantitative descriptive method approach. The place of research is at PT. XYZ Farma on line 8A. The research sample consisted of 22 data records from a population of 450 data records. Data collection techniques are observation techniques, event recording and documentation. The results showed the influence of excessive setting time, machine damage time, packaging line time stalled against operational costs of production. This is demonstrated by using AMOS, the value of C.R (Critical Ratio) exceeds the critical value $\pm 1,717$. The value of C.R for each variable is the excessive machine setting time, the length of time the machine is damaged, and the time of the packaging line has stalled towards the operational cost of production is 2,$850 ; 10,913 ; 5,330$.

Based on AMOS Standardized Regression Weight Output statistical calculations show that the duration of damage to the machine provides the greatest contribution in increasing the operational costs of production. This is indicated by the estimated coefficient value of the largest engine damage time which is $82.1 \%$. So it can be concluded that the influence of excess engine setting time, machine breakdown time and time of the packaging line has stalled to the operational costs of production with the variable length of engine damage giving the greatest contribution.
\end{abstract}

Keywords: 1. Excess time setting, 2. Duration of machine failure, 3.Time of packaging lines stopped, 4. production operational costs, 5. TPM, 6. OEE.

A. Introduction

Health is one indicator of human welfare so that it becomes a priority in nation building. One very strategic component of health is the availability of medicines as part of health services to the community. Medicine is an ingredient to reduce, eliminate disease, or cure a person from disease (http://kbbi.web.id diund 29 September 2019). According to the Food and Drug Supervisory Agency (BPOM) of the Republic of Indonesia1, drugs are substances or alloys of ingredients, including biological products, which are used to influence or investigate physiological systems or pathological conditions in the context of establishing diagnosis, prevention, healing, recovery, health improvement and contraception for human. In making medicines, comprehensive control is needed to ensure that consumers get high quality medicines. Over time, pharmaceutical companies in Indonesia began to think about accurate and quality business concepts, one of which was the implementation of total productive 
maintenance (TPM). Business concepts will be of quality if management is carried out well along with changes in decision making taken by the company. Many companies today are switching from labor-intensive systems to automation systems, where the production process carried out is mostly done by machines automatically, so quality problems are very dependent on the performance of the machines used by the company. No doubt, the company's main goal is to produce quality products with effective and efficient production processes so business profits and profits can be achieved. This can be suppressed by minimizing unplanned shutdown time. The planned unplanned stop time is the loss of unplanned company operating time such as damage to machinery / equipment so that the expected output target is not achieved.

Unplanned stop time in the production process is not only in terms of machine damage but can also be due to a delay in product release or a delay in the availability of raw materials and packaging materials. Increased waiting times due to delays in product release as well as the availability of raw materials and packaging materials can disrupt the flow of the production process so that it will certainly harm the company. Losses experienced by the company are also known as six big losses. The use of ineffective and inefficient machines / equipment as well as the delay in product release and the availability of raw materials and packaging materials are contained in six factors of six big losses. Six major losses known as six big losses are set up and adjusment loss. Potential losses from company installation and adjustment errors are delayed production time, the amount of packaging material that is wasted or even the destruction of raw materials or bulk products or called defect losses. Downtime which consists of damage to the engine or late release of the product as well as the availability of raw materials or packaging materials. Reduced speed losses are losses caused by the engine not working optimally or decreasing engine operating speed from the standard speed, and speed losses consisting of idling and minor stoppage losses caused by the frequent occurrence of the engine stopping.

In the pharmaceutical industry, adequate machinery is needed to support the smooth operation and operation. Product supply chain flow will be disrupted if there are machine constraints during the production process. Impaired supply flow of pharmaceutical products can disrupt public health stability if the required pharmaceutical products are not available in health facilities. Therefore, at this time it is very important for the pharmaceutical industry to implement an optimal machine maintenance system, a product release process flow system, demand flow and receipt of raw materials and packaging materials so as to produce optimal product output and can meet market needs.

Pharmaceutical companies are required to develop operational strategies and make continuous improvements in various aspects in an effort to achieve efficiency or improve operational efficiency and effectiveness so that they are expected to be able to reduce production costs without reducing the quality of pharmaceutical products. In connection with these efforts, the pharmaceutical company must always pay attention to the wastes caused by defects, large maintenance and maintenance costs and so on. Pharmaceutical companies are required to continue to prioritize the quality of their products in accordance with established standards by evaluating actual performance, 
comparing actual performance and handling differences that occur even though pharmaceutical companies are trying to improve effectiveness and efficiency. Product quality standards occur because of the agreement of producers and consumers. Ideally, a company may not produce the highest quality products because it can result in very expensive product prices and can potentially be inability of patients to pay or buy these products and potentially switch to using other pharmaceutical products of a similar type at more affordable prices. Therefore, the quality and quality of the product is always adjusted to the willingness of patients or consumers to pay. In connection with this, the company needs to pay attention to matters relating to quality control and production operating costs incurred.

The company chosen by the author is PT XYZ Farma Tbk. The company is one of the pharmaceutical industries engaged in medicine, medical devices, supplements, and chemicals. PT XYZ Farma Tbk is developing quite rapidly in Indonesia due to the high demand of the Indonesian people for drugs and other medical equipment facilities. Increasing public awareness of healthy lifestyles and the high need for medicines makes it a challenge and demand for the pharmaceutical industry to produce quality medicines in quantities that are able to guarantee the availability of drugs in health facilities. PT XYZ Farma Tbk has well-known products in various classes of drugs ranging from over-the-counter drugs or OTC (over the counter) to ethical drugs (prescription drugs). PT XYZ Farma is demanded for an effective production operational process so as to be able to provide quality products to around 2000 sales force, as well as the largest marketing team in Indonesia and an extensive distribution network throughout Indonesia.

Based on the above description, if PT XYZ Farma is able to reduce unplanned stop times, the company is able to reduce the potential losses arising from high operational costs. This can be realized if the company is able to maintain and maintain the machinery / supporting equipment and has a system that can prevent delays in raw materials and packaging materials. It also requires proper employee training and education so that employees are more concerned about machines and other supporting facilities. The company's success in making efficiency in relation to the production process will increase the company's competitiveness and profits. For this reason, the authors conducted a study with the topic of the influence of excessive engine setting time, machine breakdown time, and time of stopped packaging line (Linestop) on the operational costs of production. This research was carried out on the PT XYZ Farma Tbk. With this topic, this research is entitled "The Effect of Excessive Machine Setting Time, Duration of Machine Damage, and Containerized Line Time on Production Operational Costs: Study on Line 8A of PT XYZ Farma Tbk". With this title, this study aims to describe the statements as follows.

1. Effect of excess machine setting time on production operating costs.

2. The influence of the duration of damage to the engine operating costs of production.

3. The effect of the time the packaging line stops on the operational costs of production.

4. Dominant factors between over setting time, machine break time, stop packaging time which affect operational costs of production. 
B. Literature Review

1. Strategic Management

According to Taufiqurokhman, strategy management is a process of making decisions and actions that lead to the development of effective strategies or that help companies achieve their goals 13. According to Fred R. David (14, p. 5), strategy management is the science of formulating, implementing and evaluating decisions cross-functional decisions that enable the organization to achieve its objectives. Strategic management as an art and science in making (formulating), implementing (implementing), and evaluating (evaluating) strategic decisions between functions that enable the organization to achieve its goals in the future. An organization's strategic management contains three ongoing processes namely analysis, decision and action. Concern strategic management in the analysis of strategic goals (vision, mission, and strategic objectives) together with an analysis of internal and external environment. The company must take action to implement the strategy. Strategic management is a study to find out why companies can have better performance compared to others.

a. Strategy Formulation

Strategy formulation includes activities to develop the organization's vision and mission, identify external opportunities and threats of the organization, determine the strengths and weaknesses of the organization's internal, set the organization's long-term goals, make a number of alternative strategies for the organization, and choose certain strategies to use

b. Strategy Implementation

Implementation of the strategy is the company's activity to set annual goals, make policies, motivate employees, and allocate resources so that strategic formulation can be implemented. Strategic implementation includes developing a culture that supports strategy, creating effective organizational structures, and linking compensation between employees and organizational performance.

c. Strategy Evaluation

This stage is the final stage of strategic management. The stage of strategy evaluation is to review the external and internal factors which form the basis of the formulation of the strategy being applied now. Then measure performance, and take corrective actions.

2. Production and Operations Management

Management of production and operations, namely activities that regulate and coordinate the use of resources in the form of human resources, resource tools and resource funds and materials, effectively and efficiently to create and increase the utility (utility) of goods or services. Production and operations management is also a management that designs / designs, operates, and develops a productive system in completing tasks. Operations management can be carried out at banks, hospitals, factories and government. The production function includes all activities that convert inputs into goods and services. This process is related to inputs (raw materials, workers, capital / capital, machinery, and facilities), the process of changing inputs, 
and output or finished goods. Operational activities consist of 14 types of activities or decisions, namely (1) product and / or service design, (2) quality management, (3) process and capacity design, (4) spatial strategy, (5) human resources and job design , (6) supply chain management, (7) inventory management, (8) scheduling, (9) maintenance, (10) processes. (11) capacity, (12) inventory, (13) labor, (14) quality.

\section{RESEARCH METHODS}

The topic of this research is the influence of excess engine setting time, engine damage time, and time of stopped packaging line (Linestop) on the operational costs of production line 8A of PT XYZ Farma Tbk. On the basis of the research topic, the primary data of this study were observations of excessive engine setting time, engine failure time, and line time stalled (Linestop) line 8A of PT XYZ Farma Tbk. The secondary data is the document of the operational costs of production line $8 \mathrm{~A}$ of PT XYZ Farma Tbk.

The population of this research is all the time the excess engine settings, the length of the engine damage, the time of the packaging line stalled (Linestop), and document the operational costs of production line 8A of PT XYZ Farma Tbk. The sample of this research is the overtime setting of the machine, the length of the machine breakdown, the time of the packaging line stalled (Linestop), and the document of the operational costs of the production line 8A of PT XYZ Farma Tbk. during the period 2018. On the basis of research objectives, the sampling technique used was a purposive technique. namely the technique of determining the sample by establishing special characteristics in accordance with research objectives. Specific characteristics determined in the determination of this sample are the overtime setting of the machine, the duration of damage to the machine, the time of the stalled packaging line (Linestop), and the document of the operational costs of the production line 8A of PT XYZ Farma Tbk. during 2018. With a purposive technique, the sample of this study was twenty-two excess machine setting incidents, the duration of machine breakdown and the time of stopped packaging line (Linestop) during 2018 at PT XYZ Farma Tbk.

The data collection techniques of this study were observation, event recording, and documentation. Observation technique is done by direct observation of the problems that occur in the production system in the work area of the primary packaging machine line 8A PT XYZ Farma Tbk. The event recording technique in this study was used to record data on the size of the excess engine setting time, the length of the machine breakdown, the time of the stalled packaging line (Linestop), and the document of the operational costs of production line 8A of PT XYZ Farma Tbk. during 2018. The documentation technique was used to collect data on operational cost problems in the production line 8A of PT XYZ Farma Tbk. which is caused by excessive engine setting time, engine breakdown time, stop packaging time (Linestop) during 2018.

The data that has been obtained is compiled (calculated) in advance by the Overall Equipment Effectiveness (OEE) method. From the results of calculations with the OEE method, obtained data on excess setting time, machine breakdown time, and the time of the packaging line is stopped which is then linked to the operational costs of 
production. The data is then analyzed by multiple regression tests, namely data analysis involving more than two variables. The reason for using the PLS-AMOS test in data analysis is that it wants to find out the influence of the operational costs incurred by the company from the impact of the excessive engine setting time, the engine damage time, the length of time the line stalled (Linestop) on line 8A of PT XYZ Farma Tbk.

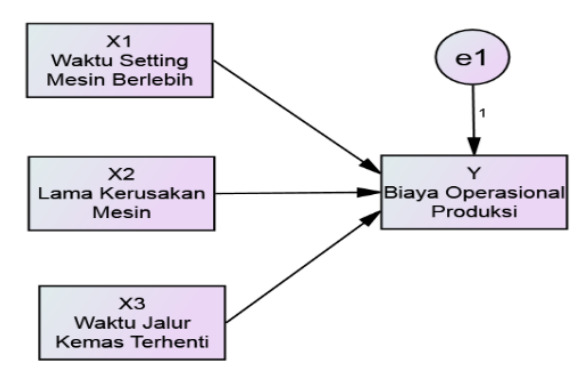

Figure 1 AMOS Regression Weight-PLS Model

\section{RESULTS AND DISCUSSION}

\section{RESULT}

Table 1 Research data

\begin{tabular}{|l|l|l|l|l|}
\hline No. & $\begin{array}{l}\text { Excess Setting } \\
\text { Time (Minutes) } \\
(\mathrm{X} 1)\end{array}$ & $\begin{array}{l}\text { Duration of engine } \\
\text { failure (Minutes) } \\
(\mathrm{X} 2)\end{array}$ & $\begin{array}{l}\text { Containerized } \\
\text { Time Stalled } \\
\text { (Minutes }) \\
(\mathrm{X} 3)\end{array}$ & $\begin{array}{l}\text { Operating Costs } \\
(\mathrm{Rp}) \\
(\mathrm{Y})\end{array}$ \\
\hline 1 & 70 & 45 & 85 & $5,757,798$ \\
\hline 2 & 70 & 105 & 120 & $7,299,465$ \\
\hline 3 & 65 & 90 & 120 & $7,768,215$ \\
\hline 4 & 45 & 60 & 60 & $5,455,715$ \\
\hline 5 & 65 & 80 & 135 & $7,414,048$ \\
\hline 6 & 75 & 105 & 85 & $7,549,465$ \\
\hline 7 & 65 & 180 & 125 & $10,091,132$ \\
\hline 8 & 75 & 120 & 180 & $8,747,382$ \\
\hline 9 & 40 & 55 & 50 & $5,111,965$ \\
\hline 10 & 45 & 70 & 55 & $5,309,882$ \\
\hline 11 & 65 & 85 & 100 & $6,591,132$ \\
\hline 12 & 55 & 110 & 90 & $8,059,882$ \\
\hline 13 & 85 & 90 & 140 & $8,601,548$ \\
\hline 14 & 65 & 60 & 85 & $6,205,715$ \\
\hline 15 & 60 & 65 & 110 & $6,299,465$ \\
\hline 16 & 60 & 85 & 70 & $5,841,132$ \\
\hline 17 & 55 & 50 & 40 & $5,518,215$ \\
\hline 18 & 50 & 40 & 45 & $5,497,382$ \\
\hline 19 & 60 & 50 & 55 & $6,184,882$ \\
\hline & & & & \\
\hline
\end{tabular}




\begin{tabular}{|l|l|l|l|l|}
20 & 70 & 110 & 85 & $7,226,548$ \\
\hline 21 & 90 & 120 & 90 & $8,164,048$ \\
\hline 22 & 70 & 80 & 75 & $6,747,382$ \\
\hline
\end{tabular}

1. Descriptive Analysis

Table 2

Descriptive Data

\begin{tabular}{|c|c|c|c|c|c|}
\hline \multicolumn{6}{|c|}{ Descriptive Statistics } \\
\hline & $\mathrm{N}$ & Minimum & Maximum & Mean & Std. Deviation \\
\hline $\begin{array}{l}\text { Waktu Setting Mesin } \\
\text { Berlebih }(\times 1)\end{array}$ & 22 & 40.00 & 90.00 & 65.2273 & 13.40551 \\
\hline $\begin{array}{l}\text { Lama Kerusakan Mesin } \\
(\times 2)\end{array}$ & 22 & 40.00 & 180.00 & 87.5000 & 35.07645 \\
\hline $\begin{array}{l}\text { Waktu Jalur Kemas } \\
\text { Terhenti }(\times 3)\end{array}$ & 22 & 40.00 & 180.00 & 90.4545 & 36.15144 \\
\hline $\begin{array}{l}\text { Biaya Operasional } \\
\text { Produksi }(\mathrm{r})\end{array}$ & 22 & 5111965.00 & 10091132.00 & 6883745.364 & 1322363.511 \\
\hline Valid N (listwise) & 22 & & & & \\
\hline
\end{tabular}

Based on table V.2 that the minimum damage time is 40 minutes, while the maximum for the machine setting time is over 90 minutes, the maximum damage time is 180 minutes and the packing time is stopped 180 minutes, so the maximum recorded time is the damage to the machine that is 180 minute.

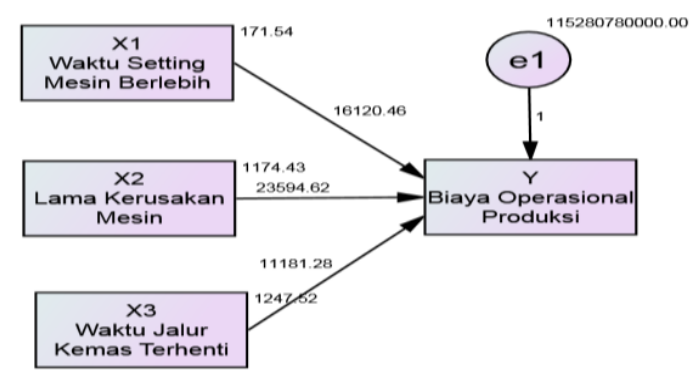

Figure 2

Output Results of Model Calculations

\section{Model Statistics Suitability Test}

The results of the calculation of the statistical suitability test of the model can be seen below.

Table 3

Index Feasibility Testing Model Structural Equation Modeling

\begin{tabular}{|l|l|l|l|}
\hline \multicolumn{1}{|c|}{ Goodness of fit index } & \multicolumn{1}{|c|}{ Cut-of value } & Analysis Results & Model Evaluation \\
\hline X2-Chi-square & 0,000 & 0,050 & good \\
\hline Significancy probability & $\geq 0.05$ & 0,000 & not good \\
\hline RMSEA & $\leq 0.08$ & 0,552 & not good \\
\hline
\end{tabular}




\begin{tabular}{|l|l|l|l|}
\hline GFI & $\geq 0.90$ & 0,648 & not good \\
\hline AGFI & $\geq 0.90$ & $-0,175$ & not good \\
\hline CMIN/DF & $<2.00$ & 7,399 & not good \\
\hline TLI & $\geq 0.95$ & 0,469 & not good \\
\hline CFI & $\geq 0.95$ & 0,735 & not good \\
\hline NFI & $\geq 0.9$ & 0,717 & not good \\
\hline PNFI & $0,60-0,90$ & 0,358 & not good \\
\hline PGFI & $\geq 0.9$ & 0,194 & not good \\
\hline
\end{tabular}

full explanation can be seen below:

a. Chi square- X2

One test tool to measure overall fit is the Chi-Square statistical likelihood ratio. The tested model will be considered good or satisfying if the Chi-Square value is low. The smaller the Chi-Square value the better the model is accepted based on the probability with a cut-off value of $\mathrm{P}>0.05$ or $\mathrm{P}>0.10 .28$. In this study the ChiSquare value obtained was 22,198 , with a $\mathrm{p}$ value $=0,000$. Thus it can be concluded that the model in this study is good.

b. RMSEA - The Root Mean Square Error Of Approximation

The RMSEA is another test tool showing the goodness-of fit that can be expected if the model is estimated in the population. RMSEA value which is smaller or equal to 0.08 is an index for the acceptance of the model that shows a close fit of the model based on the degress of freedoom. 28 Based on this study the RMSEA value obtained was 0.552 . Thus this model is considered to be unfavorable because its RMSEA value is greater than the index of the model's acceptance of 0.08 .

c. GFI - Goodness of Fit Index

GFI is a non-statistical measure that has a range of values between 0 (poor fit) to 1.0 (perfect fit). High values in this index indicate a better fit and a model can be said to be very good if the GFI value is more than or equal to 0.90 .28 The GFI value produced in this study was 0.648 . This value is less than 0.90 so it is not good enough.

d. AGFI- Adjusted Goodness of Fit Index

The recommended level of acceptance is if AGFI has a value equal to or greater than 0.90. The AGFI value produced in this study is $-0,175$, so it is not good enough.

e. CMIN / DF-The Minimum Sample Discrepancy

CMIN / DIF is one indicator to measure the fit level of a model (Ferdinand, 2000; 55). In this case CMIN / DF is nothing but a chi-square statistic, $\mathrm{X}^{2}$ divided by DF so it is called relative $\mathrm{X}^{2}$. A relative $\mathrm{X}^{2}$ value less than 2.0 or less than 3.0 is an indication of an acceptable fit between the model and data. 28 The CMIN / DF value of this research model is 7.399. Thus this model is considered to be less good because the CMIN / DF value is more than 2.0 . 


\section{f. TLI-Tucker Lewis Index}

TLI is an alternative incremental fit index that compares a model that is tested against a baseline model. 28 Values very close to 1 or more than 0.95 indicate a very good fit. 28 The TLI value produced in this study was 0.469 . Based on TLI criteria, this value is considered not good because it is less than 0.95 .

\section{g. CFI-Comparative Fit Index}

The magnitude of this index is in the range of values 0 (poor fit) to 1.0 (perfect fit). Values greater than or equal to 0.95 indicate the highest level of fit a very good fit. 28 The CFI value produced in this study was 0.735 . This value is less than 0.95 , so it is not good enough.

\section{AMOS Test Results}

Hypothesis testing is done by looking at the value of C.R. (critical ratio) contained in the AMOS output table regarding regression weights shown in table 4.6. C.R. value compared to the critical value which is identical to the calculated $t$ value of \pm 1.717 at a significance level of 0.05 , or \pm 2.508 at a significance level of 0.01 . If the value of C.R exceeds the calculated $t$ value with a significance level of 0.05 or 0.01 , then the proposed hypothesis is accepted. Conversely, if the value of C.R. does not exceed the critical value at the significance of 0.05 or 0.01 , then the hypothesis proposed is not significant. AMOS estimation results can be seen in table 4.

Table 4

AMOS Regression Weights Output

\begin{tabular}{|c|c|c|c|c|c|}
\hline & Estimate & S.E. & C.R. & $\mathrm{P}$ & decision $<0,05$ \\
\hline$Y<---X 1$ & 16120.462 & 5657.011 & 2.850 & .004 & significant positive \\
\hline$Y<---\quad X 2$ & 23594.621 & 2161.996 & 10.913 & $* * *$ & significant positive \\
\hline$Y<---\quad X 3$ & 11181.283 & 2097.708 & 5.330 & $* * *$ & significant positive \\
\hline
\end{tabular}

Hypothesis testing can be done by comparing the value of C.R in table 4 with a critical value of \pm 1.717 or $\mathrm{P}$ value (probability) with 0.05 at a significance level of $5 \%$. If the value of $C . R$ exceeds the critical value \pm 1.717 or $\mathrm{P}<0.05$, the hypothesis proposed is significant. But if the value of C.R is in the range of \pm 1.717 or $P>0.05$, it means that the proposed hypothesis is not significant. Thus it can be concluded that the test results use AMOS and produce the following results. The Over Time Setting Machine (X1) condition has a significant positive effect on the effect of Production Operational Costs. Duration of Machine Damage (X2) has a significant positive effect on the effect of Production Operational Costs. The Time Condition of the Stopped Container Line Time (X3) has a significant positive effect on the effect of Production Operating Costs.This shows that the relationship between errors that exist in AMOS is insignificant and can be said to be unrelated so that it can be assumed that there is no relationship between an error. 
Table 5

Regression Weights Output AMOS

Standardized Regression Weights

\begin{tabular}{|lll|l|}
\hline & & & Estimate \\
\hline$Y$ & $<---$ & $X 1$ & .214 \\
$Y$ & $<---$ & $X 2$ & .821 \\
$Y$ & $<---$ & $X 3$ & .401 \\
\hline
\end{tabular}

Based on table 5 AMOS Standardized Regression Weights Output, are as follows:

a. Estimate coefficient variable Over Time Machine Setting $(\mathrm{X} 1)=0.214=21.4 \%$ which shows the contribution of the variable Over Time Setting Machine (X1) to Production Operational Costs (Y) on Line 8A PT. XYZ Farma Tbk by $21.4 \%$

b. Estimate coefficient variable Machine Damage Length variable $(X 2)=0.821=82.1 \%$ which shows the contribution of the Machine Damage Length variable (X2) to Production Operational Costs (Y) on Line 8A of PT. XYZ Farma Tbk by 82.1\%.

c. Estimate coefficient of variable quality variables Stopped Container Line Time (X3) $=0.401=40.1 \%$, which shows the amount of contribution of the Stopped Container Line Time (X3) to Production Operational Costs (Y) in Line 8A of PT. XYZ Farma Tbk by $40.1 \%$. From the results mentioned above it can be concluded that the duration of the Machine Damage (X2) which has a dominant influence on Production Operational Costs (Y) on Line 8A of PT. XYZ Farma Tbk because it has the greatest Estimate coefficient of $82.1 \%$.

Table 6

Regression Weights output AMOS Squared Multiple Correlations

\begin{tabular}{|l|l|}
\hline & Estimate \\
\hline $\mathrm{Y}$ & .881 \\
\hline
\end{tabular}

Based on table 6 AMOS Squared Multiple Correlations Regression Weights Output, is the estimated coefficient on the three variables Excess Machine Setting Time (X1), Machine Damage Time (X2) and Stopped Line Time (X3) which shows the amount of contribution to Production Operational Costs (Y ) on Line 8A of PT. XYZ Farma Tbk amounted to $0.881 \times 100 \%=88.1 \%$.

Hypothesis Testing

Hypothesis testing is done using structural equation model analysis, the results of structural Equation Modeling analysis are listed in Figure 1. Based on Figure 1 it can be seen the path coefficient value. The path coefficient and significance can be seen in table. 
a. Effect of Excessive Machine Setting Time and Production Operational Costs.

Based on table 5 it can be seen that the estimated coefficient on the variable overtime setting to the operating costs of production is 0.214 . This means that there is a positive influence of the time variable Excess machine settings on production operating costs, meaning that the more there is an over setting machine, the higher the operational costs of production. The nature of the positive influence is significant, this is indicated by the calculated CR value of 2.850 and the value of $p=0.004$. The $p$ value is less than 0.05 , meaning that there is a positive and significant influence of the Excess Time Setting of the Machine on Production Operational Costs.

b. Effect of Old Machine Damage and Production Operational Costs

Based on table 5 it can be seen that the coefficient estimate on the variable duration of engine damage to the operational costs of production is 0.821 . This means that there is a positive influence of the variable duration of excess engine damage to Production Operational Costs, meaning that the longer the engine failure, the higher the operational operating costs. The nature of the positive influence is significant, this is indicated by the calculated CR value of 10.913 and the value of $p=0.000$. The value of $p$ is less than 0.05 , meaning that there is a positive and significant effect of the duration of damage to the machine against Production Operational Costs.

c. Effect of Downtime on Line Time and Production Operational Costs

Based on table 5, it can be seen that the estimated coefficient on the container path time variable stalled towards the operational operating costs of 0.401 . This means that there is a positive influence of the variable duration of excess engine damage to Production Operational Costs, meaning that the longer the engine failure, the higher the operational operating costs. The nature of the positive influence is significant, this is indicated by the calculated $C R$ value $=5.330$ and the value of $p=0,000$. The $p$ value is less than 0.05 , meaning that there is a positive and significant effect of the time the packaging line has stopped to the Production Operational Costs.

\section{Discussion}

Based on the results of this research, it can be seen that the excess engine setting time, engine damage time, and the time the packaging line has stopped has an influence on the production operational costs. This is due to the excessive machine setting time, the length of the engine failure, and the time the packaging lines are stopped will reduce the level of availability (avaibility ratio) of the machine or production equipment to be used operationally in the production process. If the equipment or production machinery has a high level of availability, it shows that the machine is ready to produce production output. Based on the results of this study, it shows that the engine damage time and excess setting time are still high so that the system needs to be repaired in an effort to reduce the setting time and machine damage time, for example to reduce the excess setting time it is necessary to standardize the parameter settings and set forth in the form of learning documents to Other operators (in the TPM book, are called one point lesson documents) so that it is expected that the operators have the same or almost the same competence in solving the problem setting machine parameters. Meanwhile, to reduce the duration of engine damage can be done by conducting a scheduled machine maintenance study and 
can be poured using tools such as a checklist. These tools are useful for keeping engine components or parts maintained and functioning properly or being able to identify and predict engine parts that will be damaged so that order can be made for machine parts that will be damaged. This will provide benefits because the engine parts that will be damaged have available new replacement parts and can prevent damage to the old engine. According to Rusli Ananta, 29 in general the level of machine availability is influenced by two factors, namely reliability and maintenance. In an effort to improve this, several things can be done as follows.

a. Improved equipment reliability

The definition of increased equipment reliability is to make the distance between the occurrence of one damage and the next damage (Mean Time Between Failure = MTBF) getting bigger / wider. Efforts that can be made include:

1) Simplify the design of existing systems in the production process.

2) Carry out preventive maintenance programs.

3) Make optimal default parameter settings.

4) Conduct regular and periodic spare parts lifetime testing studies.

b. Maintenanceability

The level of maintenance ability can be measured by calculating the average length of time needed to repair the machine in case of damage (Mean Time to Repair $=$ MTTR). The smaller the MTTR value it can be said the ability to maintain the machine will be higher. Efforts that can be made to improve the ability to maintain include:

1) Improve the ability in terms of identifying and maintaining the normal condition of the machine.

2) Providing adequate resources in accordance with company needs.

3) Increase sharpness in terms of identifying the root cause of damage that often occurs.

4) Improve the ability to plan the needs and supply of machine components.

5) Provides integrated training programs for technicians and operators.

6) Based on the results of direct observations, several factors cause over time setting, the length of time the engine is damaged and the packaging line is stopped, among others caused by factors:

a) Humans

Employees operating machinery have different educational backgrounds, namely graduates of vocational high schools (SMK) from various majors (Automotive, light vehicle engineering, mechanical engineering, computer and network engineering, etc.) as well as high school graduates majoring in Natural Sciences and Social Sciences. These different educational backgrounds affect the level of ability and skills and the speed at which employees adapt to understand the conditions of machines and other facilities. So it is necessary to do a training program and a technical competency matrix program for each employee.Lack of employee obedience and awareness of existing standards also affects the results of the coordination of a job. Strict supervision is needed so that operators and technicians are always on site to see or coordinate the machine during the process. In addition, it is necessary to provide special rewards to employees who have good work discipline and care for machines and equipment. 


\section{b) Machine}

The duration of engine damage is caused by lack of optimal periodic maintenance aimed at keeping the machine in top condition. It is necessary to review and make tools in the form of a checklist to carry out preventative maintenance so that problems that occur such as the unavailability of damaged engine parts that can prolong the time of engine damage can be prevented. Dirty engine conditions due to lack of employee care in caring for machinery / equipment (eg oil spills or dried ink) can make it difficult for employees to identify abnormalities of the machine so that the machine / equipment seems to be damaged in sudden conditions. In this case, minor cleaning needs to be done when finished doing daily work together with identifying the normality of the engine. Each part of the machine has a lifetime of use, the more often the machine is used, the machine's performance level will drop if maintenance is not performed. Machine components that are usually easily damaged due to suboptimal lubrication (lubrication) programs. Lubrication system (lubrication) is a system used to protect a machine from friction while working and prevent the engine from rust. In addition, lubrication can also be used as a cooler (cooler) for a device that rotates or rub against. The purpose of lubrication is to maintain component life and durability according to its economic life. So it is necessary to standardize the amount and type of lubricant used, because if the amount and type of lubricant do not match will affect the performance of the engine.

c) Material

The majority of the time the packaging path is stopped due to the lack of availability of primary and secondary packaging materials. At the beginning of the packaging process, employees get primary and secondary packaging materials according to the specified usage standards. Lack of packaging material availability is a domino effect of excess setting time. The longer the time needed for machine settings, the more material will be used in the project. In addition, the lack of material availability can also be caused by employees who are less thorough because of their haste in the packaging process, which causes the packaging material to be rejected so that it is necessary to make effective packaging methods and then it is included in the training program. To prevent the lack of availability of packaging materials, it is necessary to conduct a review of the packaging material procurement standards by adding buffer stock so as to prevent the packaging path time being stopped due to lack of packaging material availability. Product variations between batches related to thickness and tablet hardness can cause operator difficulties in setting up the machine and result in excessive setting time. To prevent this, it is necessary to coordinate with various parties such as the formulation department and the Quality Assurance department. The efforts that can be done are:

(1) Review of material characteristics of raw materials

(2) Review of machines and supporting tools used in processing

(3) Narrowing the specifications for the thick range of tablets

(4) Review of the processing method for proposed changes to dimensions or changes in dosage forms or the development of processing methods. 


\section{d) Method}

Self-maintenance methods as well as planned maintenance that have not been running properly have caused excessive machine setting time and engine damage. Methods for cleaning engine components that result in unidentification of engine abnormalities need to be anticipated by implementing self-maintenance as in the TPM system. In the implementation of independent maintenance on the TPM system, there are several steps that can be done, including:

1) Step 1: Initial Cleaning \& Inspection

Cleaning and checking is intended so that the cleaning process while checking the abnormalities of the machine. Important things that need to be considered in this step are spills and oil seepage, bolt wear and joints, cracked or broken machine parts, fogging on the glass so that the glass indicator / gauge is no longer readable, dust, composition and scattering on the work table, goods out of place, etc. In doing this cleaning will be identified abnormalities of the machine and areas that are difficult to clean or reach.

2) Step 2: Remove sources of dirt, parts that are difficult to clean and areas that are difficult to reach.In this step, sources that can contaminate the machine, parts that are difficult to clean and areas that are difficult to reach can be removed or minimized by means of elimination, substitution, and modification (eg closing the source area of impurities).

3) Step 3: Make an initial standard of maintenance

At this step a standardization can be made in the form of cleaning, inspection, lubrication and bolt tightness checklists.

4) Step 4: General inspection

In this step, the operator is given training on machine work and its critical points so that the operator is able to keep the machine in top condition and ready to produce quality and efficient products.

5) Step 5: Self-examination

In this step, it is necessary to compare the implementation of cleaning and inspection work with the standard guidelines and then review the presence or absence of irregularities. It is necessary to conduct audits and routine checks on equipment / machines and meetings regularly (at least 2 weeks) to always evaluate the effectiveness of work on the results

6) Step 6: Improved standards

In this step it is necessary to improve / update the activities and systems that apply, implement 6S (Sort, Set in Order, Shine, Safety, Standardize, Sustain), study the existing conditions, then do the mapping and identification of waste in the workplace associated with self care.

7) Step 7: Apply a self-maintenance system

In this step it is hoped that the habit of self-care implementation will grow by conducting daily monitoring of the implementation of self-care, being able to solve problems that arise and prevent similar problems from arising later in life and discussing achievements and irregularities in daily meetings.

The problem of replacing machine components that have not been effective because of the repair activities that are only carried out if the engine 
components are damaged and there is no planned maintenance method. Spare part management is needed to anticipate this problem by calculating the lifetime of the use of engine components so that the need for replacement of damaged machine parts becomes quickly resolved or if the lifetime of the use of engine components is approaching its lifetime can be replaced to prevent production stops due to engine damage. In spare part management, it is necessary to carry out stock taking of these components periodically and the procedure for calculating buffer stock components for short lifetimes.

e) Environment

The large number of component stacks also remains an obstacle in every process space, this can result in a longer batch replacement time so that the potential for the path time for packaging to stop. These problems can be overcome by implementing a good 5R program (Concise, Neat, Clean, Clean, Diligent). The $5 \mathrm{R}$ program is a simple method for structuring and cleaning workplaces and machinery. Piles of irregular components must be finished with the principle of concise and neat. Concise is to separate everything that is needed and not needed. Besides being concise, it also separates goods according to the frequency of need. While neat is the process of determining the location of the laying of an item with the aim of facilitating employee space in carrying out work activities. In addition, the cause of the time for packaging lines to stop is due to the non-standard release time of bulk product release which has caused the production scheduling process to be less precise. In this case, an internal risk study can be conducted for several products that have been declared resilient for release based only on the physical results of the bulk product (without waiting for the release of the results of chemical inspection. Coordination between the production department and the quality control department must be carried out to prevent any when the packaging path stops. These countermeasures must be supported and approved by all departments so that the availability loss does not occur so that production capacity increases. The daily management system program that has been established must also be evaluated regularly every month to see the effectiveness in overcoming the problems that occur in the production area.

f) Limitations

This research was conducted with several limitations of research that can influence the results of the study, the limitations that exist in this study are as follows:

1) This study only uses three dependent variables, namely Excess Machine Setting Time (X1), Machine Damage Duration (X2), and Stopped Container Line Time (X3) and one independent variable, Production Operational Cost (Y), while there are still many variables others that can be used.

2) The data used are primary data, while the sample in this study is 22 recording observations using purposive sampling techniques.

3) This research only focuses on the company Line 8A PT. XYZ Farma Tbk based on the criteria as a research sample. 


\section{E. CONCLUSIONS}

Based on the results of the analysis and discussion that was fatigued in the previous chapters regarding the effect of excess engine setting time, machine breakdown time, and time of stopped packaging lines on production operational costs: a study on line 8A of PT XYZ Farma Tbk, it can be concluded as follows:

1. The results of this test indicate the influence of the Excess Time Setting Machine (X1) variable affecting the Production Operational Costs (Y). More and more often the Time Excessive Machine Setting (X1) by 8A Line PT. XYZ Farma Tbk will further increase the Production Operating Costs (Y) at the company. Excess Machine Setting Time (X1) is proven to have an impact on the Production Operational Cost (Y) process.

2. The results of this test show that the Machine Damage Time (X2) affects the Production Operational Costs (Y). The Longer Machine Damage (X2) that occurred Line 8A PT. XYZ Farma Tbk will further increase Production Operational Costs (Y). Duration of Machine Damage (X2) is proven to have an impact on Production Operational Costs (Y).

3. The results of this test indicate the influence of the Stalled Line Time (X3) variable influences the Production Operational Cost (Y) in Line 8A of PT. XYZ Farma Tbk. This shows that the longer the Time of the Container Line Stopped (X3), the Production Operational Cost (Y) will increase. proven to have an impact on Production Operational Costs (Y).

4. The results of this test show that the variable duration of engine failure (X2) has the most dominant influence on the Production Operational Costs (Y) on Line 8A of PT XYZ Farma Tbk.

\section{REFERENCES}

Ananta, Rusli. (2017). Analisis Penerapan Total Productive Maintenance (TPM) Menggunakan Overall Equipment Effectiveness (OEE). Yogyakarta: Magister Manajemen Universitas Gadjah Mada.

Ansel. H.C. (2005). Pengantar Bentuk Sediaan Farmasi, diterjemahkan oleh Ibrahim F. Edisi IV. Jakarta: UI Press, 2005.

Assauri, Sofjan. (2008). Manajemen Produksi dan Operasi. Jakarta: Lembaga Penerbit Fakultas Ekonomi Universitas Indonesia.

David, Fred R. (2004). Strategic Management. New York: Prentice Hall International, Inc.

Depkes RI. (2005). Farmakope Indonesia Edisi V. Jakarta: Departemen Kesehatan Republik Indonesia.

Faruq, Mochamad Ammar dan Usman Indrianawati. 2014. Penyusunan Strategi Bisnis dan Strategi Operasi Usaha Kecil dan Menengah pada Perusahaan Konveksi Scissors 
di Surabaya. Jurnal Manajemen Teori dan Terapan Tahun 7 N0 3. Desember 2014, hal 173-198.

Ferdinand. (2005). Metode Penelitian Manajemen Edisi 2. Semarang : BP Universitas Diponegoro.

Ghozali, Imam. (2013). Aplikasi Analisis Multivariate dengan Program IBM SPSS 21 Update PLS Regresi. Semarang: Badan Peneribit Universitas Diponegoro.

Hadisoewignyo L, Fudholi A. (2013). Sediaan Solida.Yogyakarta : Pustaka Pelajar.

Heizer J, Render B. (2014). Operation Management: Sustainability and Supply Chain Management. 11th Edition. London: Pearson.

Julianti, Ellisa dkk. (2006). Bahan Ajar Teknologi Pengemasan. Medan: Universitas Sumatera Utara.

Karuppuswamy, P dkk. (2007). Application of computerized maintenance management system coupled with risk management techniques for performance improvement of manufacturing systems. UK: International Journal of Business Performance Management Vol 9 No. 1; 2007. P. 7-21.

Kotler dan Keller. (2009). Manajemen Pemasaran Jilid I Edisi ke 13. Jakarta : Erlangga; 2009. Hal 27.

Kepala Badan Pengawas Obat dan Makanan Republik Indonesia. (2012). Peraturan Kepala Badan Pengawas Obat dan Makanan Republik Indonesia nomor HK.03.1.33.12.12.8195 tahun 2012 tentang Penerapan Pedoman Cara Pembuatan Obat yang Baik. Jakarta: Badan Pengawas Obat dan Makanan.

Nakajima, Seichi. (1984). Introduction to TPM (Total Productive Maintenance). Tokyo: Productivity Press, Inc.

Peraturan Menteri Kesehatan Republik Indonesia Nomor 1799/MENKES/PER/XII/2010 tentang industri farmasi. Jakarta: Berita Negara Republik Indonesia Tahun 2010 Nomor 721, Menteri Hukum dan Hak Asasi Manusia.

Russel, Roberta S, Taylor Bernard W. (2009). Operations Management: Along the Supply Chain. Sixth Edition. US: John Wiley \& Sons, Inc.

Sampurno. (2013). Manajemen Stratejik : Menciptakan Keunggulan Bersaing yang Berkelanjutan. Cetakan ketiga. Jogjakarta: Gajah Mada University Press.

Siregar, C.J.P., dan Wikarsa, S. (2010). Teknologi Farmasi Sediaan Tablet Dasar - Dasar Praktis. Jakarta: Penerbit buku Kedokteran EGC.

Stevenson, W J. (2012). Operation Management. 11th Edition. New York : McGrawHill/Irwin.

Taufiqurokhman.(2016). Manajemen Strategik. Cetakan pertama. Jakarta: Fakultas Ilmu Sosial dan Ilmu Politik Universitas Prof. Dr. Moestopo Beragama. 
Undang-Undang Republik Indonesia nomor 36 tahun 2009 tentang Kesehatan.

Venkatesh J. (2007). An Introduction to total productive Maintenance (TPM). 2007. Diakses dari http://www.plant-maintenance .com/articles/tpm intro. tanggal 02 Agustus 2018.

Widyarto, Agus. (2012). Peran Supply Chain Management dalam Sistem Produksi dan Operasi Perusahaan. Surakarta: Benefit Jurnal Manajemen dan Bisnis Vol 16 No 2; 2012.

Zainuddin, Muhamad. (2011) Metodologi Penelitian Kefarmasian dan Kesehatan. Cetakan Pertama. Surabaya: Airlangga University Press;, 50-52. 